\title{
PENGARUH PEMBERIAN JUMLAH TAKARAN RAGI TERHADAP KANDUNGAN PROTEIN YANG DIHASILKAN PADA TEMPE BIJI NANGKA (Artocarpus heterophyllus)
}

\author{
Harmoko ${ }^{1}$ \\ Agus Sutanto $^{2}$ \\ Kartika Sari ${ }^{2}$ \\ ${ }^{1}$ Dosen PendidikanBiologiSTKIP PGRI Lubuklinggau \\ ${ }^{2}$ Dosen Pendidikan Biologi Universitas Muhammadiyah Metro \\ e_mail: putroharmoko@gmail.com
}

\begin{abstract}
Jackfruit (Artocarpusheterophyllus), is well known in Indonesia, when the fruit is ripe jackfruit can be consumed. After we consume jackfruit, we'll leave the trash in the form of jackfruit seed, which has not been used by the community to the fullest. The purpose of this study are trying to explore another potential of jackfruit seeds and increasing the protein content of jackfruit seeds by processing in to tempeh. Another purpose is knowing the number yeast of doses that can produce in tempeh of jackfruit seeds. This research uses 4 treatments (A: 0.25 grams yeast/50 grams jackfruit seed, B: 0.50 grams yeast $/ 50$ grams jackfruit seeds, C: 0.75 gram yeast $/ 50$ grams jackfruit seeds, and D: 1 grams yeast/50 grams of jackfruit seeds) with 4 repetitions. Test protein content tests conducted at the Laboratory of Food Technology and Agricultural Faculty of Agricultural Technology, GadjahMada University (UGM). Treatment A produced protein average of $2,64 \%, B$ produced protein average of $3,429 \%$, treatment $C$ produced protein average of $4,146 \%$ and treatment $D$ produced protein average of $5,635 \%$ protein. The highest protein content is produced by treatment $D$.
\end{abstract}

Keywords: Takaran ragi, tempe biji nangka (Artocarpusheterophyllus),kandungan protein.

Buah nangka (Artocarpus heterophyllus), sudah tidak asing lagi dengan kehidupan masyarakat Indonesia, karena buah ini adalah salah satu buah yang mudah didapatkan dan dikembangbiakkan. Buah nangka memiliki kulit yang dilindungi dengan duri. Setiap buah mengandung lebih dari 500 biji yang besar yang dapat dimakan dan mengandung zat tepung, yang kadang-kadang disebut juga breadnut

(Kurniawan, 2006:51).Permasalahan yang timbul setelah kita mengkonsumsi daging buah nangka, kita akan meninggalkan sampah yang berupa biji nangka. Tentunya akan menimbulkan sampah dan mengganggu pandangan mata.
Bijinangka (beton, Jawa) belum dimanfaatkan oleh masyarakat secara maksimal. Biji nangka bisa dimanfaatkan sebagai alternative makanan pengganti oleh masyarakat. Biasanya biji nangka dikonsumsi dengan cara direbus, dimakan saat sore atau malam hari sebagai teman berkumpul dengan keluarga dan menonton TV. Salah satu inovasi dari biji nangka ialah dengan membuatnya menjadi tempe. Mengingat tempe merupakan makanan khas masyarakat Indonesia, yang murah, dan memiliki kandungan gizi yang tinggi, maka diharapkan tempe biji nangka jugaakan digemari konsumen sekaligus 
menjadi sumber protein tambahan sebagai mana tempe kedelai.

Tabel 1. Komposisi Gizi 100 Gram Biji Nangka dan Kacang Kedelai

\begin{tabular}{l|c|c}
\hline Zat makanan & Kacang Kedelai & Biji Nangka \\
\hline Karbohidrat & $30,1 \mathrm{~g}$ & $36,7 \mathrm{~g}$ \\
\hline Protein & $30,2 \mathrm{~g}$ & $4,2 \mathrm{~g}$ \\
\hline Lemak & $15,6 \mathrm{~g}$ & $0,1 \mathrm{~g}$ \\
\hline Air & $20,0 \mathrm{~g}$ & $75,7 \mathrm{~g}$ \\
\hline Kalsium & $0,196 \mathrm{~g}$ & $0,033 \mathrm{~g}$ \\
\hline Fosfor & $0,506 \mathrm{~g}$ & $0,200 \mathrm{~g}$ \\
\hline Besi & $0,0069 \mathrm{~g}$ & $0,001 \mathrm{~g}$ \\
\hline Vitamin A & $0,095 \mathrm{~g}$ & $0 \mathrm{~g}$ \\
\hline Vitamin B1 & $0,00093 \mathrm{~g}$ & $0,0002 \mathrm{~g}$ \\
\hline Vitamin C & $0 \mathrm{~g}$ & $0,010 \mathrm{~g}$ \\
\hline
\end{tabular}

Sumber: Direktorat Gizi RI (dalam Hayati 2009:20).

Sarwono (2008:1) menyatakan bahwa "Tempe merupakan makan an tradisional yang telah lama dikenal di Indonesia. Makanan tersebut dibuat dengan cara fermentasi atau peragian." Dalam pembuatan tempe, ragi diperlukan untuk membantu proses fermentasi supaya bahan menjadi tempe.

Inokulum tempe merupakan kumpulan spora kapang dan jamur yang digunakan untuk bahan pembibitan dalam pembuatan tempe (Sukardi, et.al, 2008).Selain kapang, proses fermentasi tempe juga dibantu oleh bakteri, diantaranya: Lactobacillus $s p$, Streptococcus sp, Pediococcus sp dan Bacillus $s p$, dan khamir yang berperan yaitu Saccharomyces cerevisae (Andayani, et.el, 2008:96).

Masyarakat Indonesia pada umumnya membuat tempe dari kacang kedelai. Perbandingan gizi biji nangka dengan kacang kedelai dapat dilihat pada Tabel 1.

Berdasarkan Tabel 1 di atas, terlihat bahwa kadar potein biji nangka lebih sedikit jika dibandingkan dengan kacang kedelai, sehingga perlu penelitian lebih lanjut untuk meningkatkan kadar protein, salah satu usahanya adalah dengan membuatnya menjadi tempe dengan bantuan ragi.
Untukmembuattempetidakterlepasdari yang namanyaragi, ragidimanfaatkansebagaipembantudala $\mathrm{m}$ proses fermentasi. Tempe merupakansumber protein nabati yang sangatmurahbagimasyarakatkelasbawa h. Budi (2008:39) menyatakanbahwa: "protein merupakanzatgizi yang sangatpentingbagitubuhmanusia,

karenaberperansebagaizatpembangunda nmengaturmetabolismetubuh."Berdasar kan latar belakang tersebut, maka perlu dikaji mengenai pengaruh jumlah takaran ragi terhadap kandungan protein pada tempe biji nangka.

\section{METODE}

Jenis penelitian yang digunakan adalah eksperimen yaitu dengan menggunakan takaran ragi yang berbeda pada tempe biji nangka. Dalam penelitian ini menggunakan 3 perlakuan dan satu control serta dilakukan 4 pengulangan untuk masing-masing perlakuan. Takaran ragi yang digunakan yaitu 0,50 gram sebagai kontrol; 0,25; 0,75; dan 1 gram ragi sebagai perlakuan. Biji nangka yang digunakan diambil dari Kota Metro. Untuk uji kandungan protein dilakukan di Laboratorium Teknologi Pangan dan Hasil Pertanian Fakultas 
Teknologi Pertanian Universitas Gadjah Mada.

\section{A. PopulasidanSampelPenelitian}

\section{PopulasiPenelitian}

Dalam penelitian ini yang menjadi populasinya adalah biji nangka yang akan dijadikan tempe. Supaya homogen, biji nangka diambil dari buah yang sama. Biji nangka dipotong menjadi 3 bagian, dan setiap bungkus tempe harus mempunyai bagian-bagian itu.

\section{SampelPenelitian}

Sampel yang digunakan adalah tempe biji nangka sebanyak 50 gram dari masingmasing beratragi yang diberikanperlakuan.

\section{B. ProsedurPenelitian}

\section{Cara Kerja Pembuatan TempeBijiNangka}

a. Biji nangka dicuci dengan air bersih dan selanjutnya dijemur sampai kering yang berfungsi untuk mengurangi kadar air setelahdicuci.

b. Biji nangka kemudian direbus, yang bertujuan untuk melunakkan biji.

c. Setelah direbus, kemudian biji nangka direndam.

d. Kemudian dicuci dengan air kembali sampai bersih, biji nangka yang telah dikupas kulitnya.

e. Biji nangka dikukus dan biji nangka ditiriskan yang telah dikukus.

f. Ditaburi dengan 0,5 gram ragi untuk setiap 50 gram sebagai kontrol, 0,25 sebagai perlakuan pertama, 0,75 gram sebagai perlakuan kedua, 1 gram sebagai perlakuan ketiga dan diaduk sampai rata.

g. Dibungkus dengan daun pisang dandifermentasikan selama36 jam.

2. Penentuan Kadar Protein (Metoda Gunning)

a. Bahan (tempebijinangka) yang telah dihaluskankemudianditimba ngsebanyak $0,5-1,0$ gr dan dimasukkan kedalam labu Kjeldahl, ditambahkan 10 gr $\mathrm{K}_{2} \mathrm{~S}$ atau $\mathrm{Na}_{2} \mathrm{SO}_{4}$ anhidrat, dan $10-15 \mathrm{ml} \mathrm{H}_{2} \mathrm{SO}_{4}$ pekat. Kalau distruksi sukar perludilakukanpenambahan $0,1-0,3$ gr $\mathrm{CuSO}_{4}$ dan gojok.

b. Kemudian dilakukan distruksi diatas pemanas listrik dalam lemari asam. Mula-mula dengan api kecil, setelah asap hilang api dibesarkan, pemanasan diakhiri setelah cairan menjadi jernih sedikit kebiruan.

c. Dibuat perlakuan blanko, yaitu perlakuan diatas tanpa sampel.

d. Setelah dingin, ditambahkan $100 \mathrm{ml}$ aquades kedalam labu kjeldhal, serta larutan $\mathrm{NaOH} 45 \%$ sampai cairan basis. Dipasang labu Kjeldhal dengan segera pada alat Distilasi.

e. Dipanaskan labu Kjeldhal sampai amonia menguap semua, lalu ditampung pada distilat dalam erlenmeyer berisi $25 \mathrm{ml} \mathrm{HCl} 0,1 \mathrm{~N}$ yag sudah diberi indikator fenolfptalein $1 \%$ beberapa tetes. Diakhiridistilasi setelah distilat tertampung sebanyak $150 \mathrm{ml}$ atau setelah 
distilat yang keluar tidak berbasis.

f. Jikakelebihan $\mathrm{HCl} \quad 0,1 \mathrm{~N}$ dalam distilat, dititrasi dengan larutan $\mathrm{NaOH} 0,1 \mathrm{~N}$ hingga warna merah muda, dicatat jumlah $\mathrm{NaOH}$ yang digunakan.

$\% \mathrm{~N}=$

$(\mathrm{ml} \mathrm{NaOH}$ blanko $-\mathrm{ml} \mathrm{NaOH}$ contoh $) \times \mathrm{N} \mathrm{NaOH} \times 14,008$ gr. sampel $\times 1000$

$\%$ Protein $=\% \mathrm{~N} \times$ aktor konversi

DiadaptasidariKusnanto (2012:38).

\section{TeknikPengumpulan data}

Tempe biji nangka yang mendapat perlakuan dengan takaran ragi yang berbeda, kemudian dianalisis kadar proteinnya di Laboratorium Teknologi Pangan dan Hasil Pertanian Fakultas Teknologi Pertanian Universitas Gadjah Mada. Sampel tempe biji nangka yang dianalisis kandungan proteinnya sebanyak 16 sampel dengan 4 perlakuan.

\section{HASIL}

Perlakuan pertama menggunakan ragi 0,25 gram $/ 50$ gram biji nangka menghasilkan protein rata-rata $2,64 \%$, perlakuan kedua menggunakan ragi 0,5 gram $/ 50$ gram biji nangka menghasilkan protein dengan rata-rata $3,429 \%$. Sedangkan perlakuan ketiga menggunakan ragi 0,75 gram/50 gram biji nangka menghasilkan protein ratarata $4,146 \%$ dan perlakuan keempat menggunakan ragi 1 gram/50 gram biji nangka menghasilkan rata-rata protein sebesar 5,635\%. Grafik kenaikan kandungan protein pada tempe biji nangka dengan 4 perlakuan dapat dilihat pada Gambar 1.

\section{PEMBAHASAN}

nangka

Kandungan protein tempe biji menggunakan metode Gunning yang dilaksanakan di Laboratorium
Teknologi Pangan dan Hasil Pertanian Fakultas Teknologi Pertanian Universitas Gadjah Mada. Data kandungan protein pada tempe biji nangka diperoleh dari 4 perlakuandan 4 pengulangan. Penambahan jumlah takaran ragi yang berbeda pada tempe biji nangka memberikan hasil yang berbeda untuk tiap perlakuan. Direktorat Gizi (dalamHayati 2009:20), menyatakan bahwa: "protein yang terkandung dalam 100 gram biji nangka adalah sebanyak $4,2 \%$ protein". Iniberarti 50 gram biji nangka akan menghasilkan $2,1 \%$ protein. Pada Gambar 6 terlihat grafik kenaikan kandungan protein tempe biji nangka setelah diberikan perlakuan. Perlakuan pertama 0,25 gram ragi/50 gram biji nangka menghasilkan potein dengan rata-rata $2,621 \%$ dan perlakuan kedua 0,5 gram ragi/50 gram biji nangka menghasilkan protein dengan rata-rata $3,429 \%$. Perlakuan ketiga 0,75 gram ragi/50 gram biji nangka menghasilkan protein dengan rata-rata $4,152 \%$ dan perlakuan terakhir 1 gram ragi/50 gram biji nangka menghasilkan protein dengan rata-rata 5,627\%.

Penambahan jumlah takaran ragi 1 gram $/ 50$ gram biji nangka menghasilkan kandungan protein tertinggi yaitu dengan rata-rata $5,627 \%$, sedangkan yang terendah pada takaran 0,25 gram ragi/50 gram biji nangka yang menghasilkan kandungan protein dengan rata-rata $2,621 \%$. Hidayat, et.al (2006:101) menyatakan bahwa: "adanya enzim proteolitik menyebabkan degradasi protein menjadiasam amino, sehingga nitrogen terlarut meningkat dari $0,5 \%$ menjadi 2,5\%". Peningkatan kadar nitrogen yang semakin banyak otomatis akan menghasilkanasam amino semakin banyak, karena penyusun asam amino dan protein adalah unsur nitrogen. 


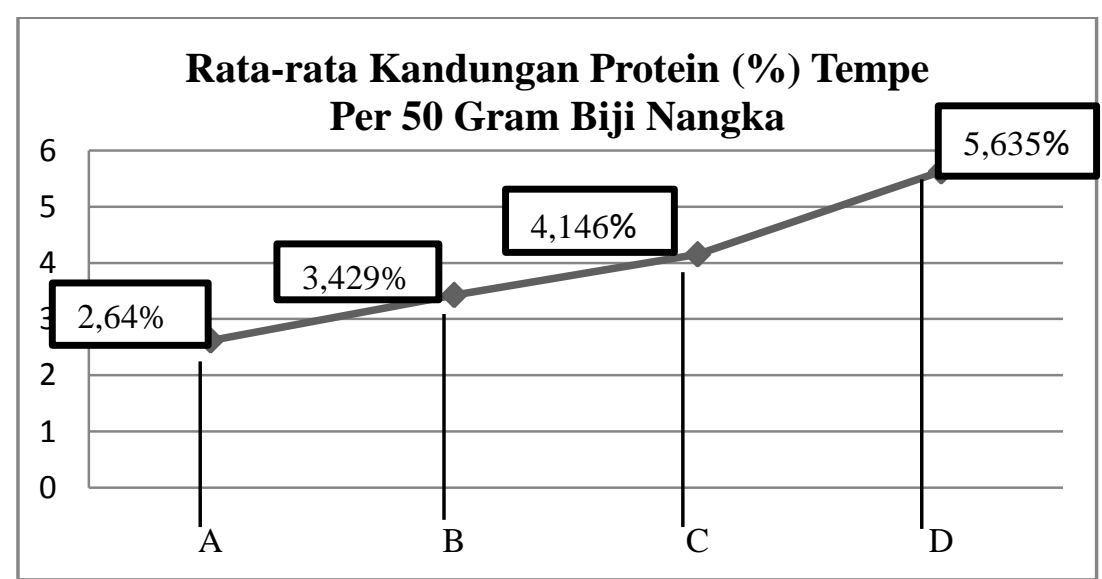

Keterangan:

A: 0,25 gram ragi, B: 0,5 gram ragi, C: 0,75 gram ragi, D: 1 gram ragi.

Gambar 1. Grafik Rata-rata Kandungan Protein Tempe Per 50 Gram Biji Nangka

Tabel 2. Perbandingan Protein Biji Nangka Sebelum Diolah dan Protein Biji Nangka Setelah Dibuat Tempe serta Protein Tempe Kedelai (Per 100 Gram)

\begin{tabular}{rl|c}
\hline \multicolumn{2}{c|}{ JenisBahandan Tempe } & Kandungan Proteindalam Tempe Per 100 Gram \\
\hline $\begin{array}{r}\text { 1. } \\
\text { a. }\end{array}$ & Bempe BijiNangka \\
\hline b. & SudahDiolah (Mentah) \\
$1) \quad$ perlakuan A & DirektoratGizi (dalamHayati 2009:20). \\
\hline & $5,28 \mathrm{~g}$ \\
\hline 2) & Perlakuan B & $6,858 \mathrm{~g}$ \\
\hline 3) & Perlakuan C & $8,292 \mathrm{~g}$ \\
\hline 2. & Terlakuan D & $11,27 \mathrm{~g}$ \\
\hline
\end{tabular}

Keterangan:

A: 0,25 gram ragi, B: 0,5 gram ragi, C: 0,75 gram ragi, D: 1 gram ragi

Dwidjoseputro (2005:152) menyatakan bahwa: "Rhizopusoryzae, dapat mengubah amilum menjadi dekstrosa, dapat memecah protein dan lemak yang ada di dalam sel-sel kedelai dan kacang, dengan demikian tempe mudah dicerna oleh tubuh". Jamur Rhizopus oryzae yang terkandung dalam tempe biji nangka, pada mulanya berasal dari ragi yang ditambahkan saat pembuatan tempe biji nangka berlangsung. Spora jamur kemudian tumbuh dan berkembang pada bahan tempe, yaitu biji nangka. Lambat laun spora akan tumbuh dan melakukan proses fermentasi, mengubah biji nangka menjaditempe. Fermentasi ini akan merombak protein menjadi asam amino yang mudah dicerna manusia, yang dibantu oleh enzim proteolitik.

Perbandingan kandungan protein biji nangka yang belum diolah, sudah diolah (diberiperlakuan jumlah takaranragi) dan tempe kedelai seperti terlihatpadaTabel 2

BerdasarkanTabel2tersebut, protein mengalam ikenaikan setelah 
diberikanperlakuan dengan jumlah takaran ragi. Sebelum diolah kandungan protein biji nangkasebesar $4,2 \%$, namun setelah diberiperlakuan meningkat menjadi $5,28 \%$ untuk perlakuan A, $6,858 \%$ untuk perlakuan B, 8,292\% untuk perlakuan $\mathrm{C}$ dan $11,27 \%$ untuk perlakuan D. sedangkan kandungan protein tempe kedelai 18,3\%. Dapat dilihat bahwa kenaikan jumlah kandungan protein tempe biji nangka masih memungkinkan untuk bertambah kembali.

\section{KESIMPULAN DAN SARAN}

\section{A. Kesimpulan}

1. Terdapat pengaruh jumlah takaran ragi yang diberikan terhadap kandungan protein yang dihasilkan pada tempe biji nangk ada setiap perlakuan bepengaruhnya (signifikan).

2. Pada jumlah takaranragi 1 gram untuk 50 gram tempe biji nangka menghasilkan kandungan potein tertinggi yaitu $5,627 \%$.

\section{B. Saran}

1. Bagi peneliti lainnya

a. Sebaiknya dilakukan upaya untuk meningkatkan kandungan protein dengan menambahkan bahan yang memiliki kandungan protein tinggi.

b. Pemanfaatan biji nangka menjadi alternatif makanan lain.

c. Kecenderungan kandungan protein masih meningkat pada tempe biji nangka, sehingga perlakuan pada ragi bisa ditambah sampai batas tertentu.

2. Bagi masyarakat.

Dapat memberikan informasi kepada masyarakat umum, tentang pemanfaatan biji nangka sebagai tempe.

\section{DAFTAR PUSTAKA}

Andayani, P., Agustin K. W., danErni S. M. 2008. Isolation and Identification of Microorganism in Brown Sorgum Tempeh (Sorgum bicolor) and Its Potency For Degrading Starch and Protein.

JurnalTeknologiPertanian. (Online), Vol. 9, No. 2 (Agustus 2008)Hal. 95-105. (http://www.jtp.ub.ac.id, diakses 22 Oktober 2012).

Budi M, EkodanLiliek H. 2008. GizidanKesehatanPerspektif AlqurandanSains. Malang: UINMalang Press.

Dwidjoseputro. 2005. DasardasarMikrobiologi. Jakarta: Djambatan.

Hayati, Salma. 2009. PengaruhWaktuFermentasiTerha dapKualitas dariBijiNangka

(Artocarpusheterophyllus)

danPenentuan Kadar ZatGizinya. Skripsitidakditerbitkan. Medan: Universitas Sumatera Utara.

Hidayat, N., Padaga, M.C., danSuhartini, $\quad$ S. 2006. MikrobiologiIndustri.

Yogyakarta: PenerbitAndi.

Kurniawan, Iwan. 2006. MengenalBuah-buahan.

Bandung: Jembar.

Kusnanto, Febri. 2011. Pengaruh Lama Fermentasipada Tempe BijiKaret (Haveabrasiliensis)

TerhadapKandungan Protein danUjiOrganoleptikSebagaiSumb erBelajarBiologi SMA Kelas XII padaMateriBioteknologiPangan. Skripsitidakditerbitkan. Metro: 
UniversitasMuhammadiyah Metro.

Sarwono. 2008. Membuat Tempe danOncom. Jakarta: PenebarSwadaya.

Sukardi., Wignyanto dan Isti Purwaningsih. 2008. Uji Coba Penggunaan Inokulum Tempe dari Kapang Rhizopus oryzae dengan Substrat Tepung Beras dan Ubi Kayu pada Unit Produksi Tempe Sanan Kodya Malang. Jurnal Teknologi Pertanian. (Online), Vol. 9 No. 3 (Desember 2008) $207 \quad-\quad 215$. (http://www.jtp.ub.ac.id, diakses 22 Oktober 2012). 